\title{
Grappling with the Economy of Enrichment
}

\author{
Luc Boltanski and Arnaud Esquerre \\ (in conversation with Fabian Muniesa)
}

\begin{abstract}
In a conversation with Fabian Muniesa from the board of editors of Valuation Studies, Luc Boltanski and Arnaud Esquerre unravelled a few of the distinguishing features of their new work on the sociology of valuation. Combining an updated view on the pragmatics of justification and a more recent preoccupation with the problem of prices, their proposal appears as both a suitable contribution and a timely challenge to current threads in valuation studies. It also interacts in a stimulating fashion with their concomitant analysis of the political atmosphere in France, and more widely of the shift to identity that so vividly informs the critique of capitalism today.
\end{abstract}

\section{Fabian Muniesa (FM):}

Value is a trending topic in the social sciences today, with countless developments in the sociology of valuation regimes, valuation devices, valuation controversies and valuation struggles. What would be your prime diagnosis of this pattern?

Luc Boltanski,EHESS, boltansk@ehess.fr

Arnaud Esquerre, CNRS, arnaud.esquerre@mae.u-paris10.fr

Fabian Muniesa, Mines ParisTech, fabian.muniesa@mines-paristech.fr

(C) 2015 Luc Boltanski and Arnaud Esquerre

LiU Electronic Press, DOI 10.3384/VS.2001-5592.153175

http://valuationstudies.liu.se 


\section{Luc Boltanski (LB):}

The preoccupation with value goes hand in hand with a sense of crisis in valuation, a sense that has certainly been precipitated by the global financial crisis of the late 2000s and by the many commentaries, critiques and interpretations that unfolded. The preoccupation is often controlled, within that context, by a problematic tension between some kind of value that would be spurious and some other kind of value that would be sound, as in the contrast often drawn between what has been termed "casino finance" on the one hand and the "real economy" on the other. This tension is of course a source of disorientation, a disorientation that parallels the difficulties the sociology of valuation is frequently stuck with, trapped as it often is between constructivism and realism, between the revelation of arbitrariness and the demonstration of a rationale.

The preoccupation with value is also prompted, we believe, by the recognition of the epochal shift to an "economy of enrichment", which is the term we suggest in order to refer to the forms of wealth creation that are based on an economic exploitation of the past, in the form of craft, heritage, tradition, identity or, more largely, culture. ${ }^{1}$ The idea of enrichment refers to the act of improving the value of something, but we should also understand it in its material connotation, as when we speak of the enrichment of mineral ore. France is an excellent example of an economy almost entirely oriented towards this model of worth, based on the enrichment of legacy and uniqueness.

\section{Arnaud Esquerre (AE):}

On a conceptual level, the sociological preoccupation with value today is also characterized by a shift from sociology of persons to sociology of things, with all that this entails in terms of attention to sensitive characteristics, material operations and linguistic repertoires. This shift of position certainly raises a number of challenges, a crucial one being the need to find new ways to approach the problem of difference and domination, and to approach this challenge from within valuation processes proper.

\section{FM:}

Your current investigation on the "economy of enrichment" runs parallel to your political critique of the mounting agenda of social nationalism in France. Is there a link?

\footnotetext{
${ }^{1}$ Part of this research is presented in French in Boltanski and Esquerre (2014a). A more complete book is currently in preparation.
} 


\section{LB:}

The political atmosphere in France today is certainly characterized by a sense of revaluation of identities, values and attachments in general and of national identity in particular. This is quite clearly encapsulated in the renewal of the political discourse of the National Front under the leadership of Marine Le Pen ${ }^{2}$ - but not in that alone. And our concern encompasses multiple forms of demands for true value, true people and true land. Is the sociological preoccupation with value assessing this situation critically? Or is it contributing to its development? This is obviously an open question, certainly a complicated concern on which we should keep a very attentive eye.

\section{AE:}

But our inquiry on the "economy of enrichment" is certainly not absorbed into these kinds of considerations. One thing is our concern for current political discourse in France. And another, quite different, thing is our investigation into how the economic value of something is determined, in the form of a price, when that element enters, for instance, the logic of a collection, which is for us a key form of the "economy of enrichment". The fact that those two problems seem to talk to each other is, in fact, the product of this inescapable ambiguity that the very notion of "value" does carry.

\section{LB:}

Yes, there is certainly something fuzzy about the notion of value, especially in the field of economic sociology in which this fuzziness is sometimes conscientiously cultivated. The price we pay for not dissipating that fuzziness is, precisely, that the crucial problem of prices is maintained in the dark.

\section{FM:}

Your project is in part precisely about redressing that tort. What do you make of value, then, in relation to prices?

\section{LB:}

We suffer from the legacy of the tradition of classical political economy, which basically consisted in developing a critique of prices on the grounds of something different that things would have, namely their value, the study of which would constitute the domain of economic science. Neoclassical economics abandoned to some extent this quest for the basis of value, but kept value alive, encapsulating it

2 See Boltanski and Esquerre (2014b). 
for instance in the machinery of utility, eventually in a philosophy of subjective preferences. Our position is different, and very simple. It is in fact a follow-up on the pragmatist position we have been developing in past work. ${ }^{3}$

The first step is to analyse things not in and by themselves but in the moment in which they change hands, a moment that we can very well consider as a "trial". The result of such trial is a price, which is a fact, expressed in the metrics of money. What is "value" here? Well, value is certainly something people involved in this trial sometimes refer to, but by no means always. So we therefore need to examine the pragmatic circumstances in which people invoke that notion. What do we discover? Value talk only happens in situations in which there is a problem with the price. The notion of value is used when there is a situation in which a price ought to be criticized or justified, for example in order to claim that the thing under consideration is overpriced or underpriced, i.e. that its "value" has been overestimated or underestimated. So what is the function of "value"? It is a justification of the price, plain and simple.

\section{FM:}

You define value as "a device for the justification of prices". 4

\section{LB:}

Indeed. Evidently, when the justification process is led towards higher levels of generalization, this device can meet the orders of justification that Laurent Thévenot and I identified in our pragmatic sociology of common superior principles. ${ }^{5}$ But the "values" we dealt with there are shaped in disputes whose prime issue is justice. This is different from the case of the commercial transaction. The issue at stake here, if at all, is the justification for the price. And our standpoint is definitely not to start with value or values, but with prices as events that only sometimes would require an apparatus of justification.

\section{FM:}

That said, your earlier work on the so-called "economies of worth" has been insistently used in economic sociology in another manner, namely as an invitation to identify different "value regimes" that are invoked in the course of economic life, with several "values", and not only one, being translated or not, poorly or fairly, in market appraisal. Not quite the same take.

\footnotetext{
${ }^{3}$ See especially Boltanski and Thévenot (2006); Boltanski and Chiapello (2005).

4 "Nous définirons la valeur comme un dispositif de justification du prix" (Boltanski and Esquerre 2014a, 21).

${ }^{5}$ See again Boltanski and Thévenot (2006); also Boltanski (2012).
} 


\section{LB:}

Sure. But the fact that we know that approach well (in part because we contributed to building it) puts us in a good position to divert from it and to understand its weaknesses.

\section{AE:}

In our present work we identify several forms of the "economy of enrichment". These certainly do not correspond to different "values" people would have. They rather correspond to different techniques of valuation, in the sense of different apparatuses that would provide the justification for prices with a set of notable characteristics, historically situated. One dominant form would be, for instance, the "collection form", which is essentially based on references to the past and, more precisely, to what we call the "memorial force" of things. Value narratives focused on traditions, genealogies, identities and pedigrees provide clear examples of that, from the collectable antique to the terroir vineyard. And it is true that sometimes these narratives might coincide with the political repertoire of national identity.

\section{FM:}

You clearly signal that in your observations on the current nationalist syndrome in France. "France", as a brand, clearly has to do with the preservation of a singular sense of identity: beautiful castles, complicated cheese, expensive bottles, things whose value runs the risk of being destroyed if plunged into a cosmopolitan cocktail. One may read there, perhaps implicitly, a connection between the marketing of French singularity as an economic model and the potential of national values, such as expressed in the notion of the "terroir".

\section{AE:}

That intuition is obviously there, but, as we said, this is not our prime analytical claim.

\section{LB:}

Indeed, the crux of our argument is rather on the issue of prices. It may be the case that the value of a bottle of wine is controlled by a narrative of land and custom, but what is of interest to us is that, for it to be fully part of this "collection form" of capitalism that we aim at delineating, it needs to refer to the past in a particular manner in order to justify a high price. The price question is the crucial one, but it is obscured by the value question.

\footnotetext{
6 See Boltanski and Esquerre (2014b).
} 
FM:

You also suggest an important macroeconomic argument, which is that today the world economy seems to be leaning towards an economic order organized around the production of expensiveness.

AE:

The production and circulation of expensive objects is clearly related to the expansion of a globally narrow, but indeed quite populous, wealthy class. It is not only that the rich are getting richer and accordingly require, in order to thrive, a marketing of distinction and exclusivity. Expensive objects need stability and liquidity: their price should not decrease, rather increase steadily, and it should be possible to resell them easily. We look at the devices that allow fulfilling that twofold condition.

\section{LB:}

It could be argued that we are just looking at what has been called "post-industrial societies". But this is not the case. Our view is not that the industrial world is disappearing, quite the contrary. We observe an outstandingly important rise of the industrial world over the last thirty to forty years, with formerly non-industrial countries becoming industrial and with new forms of industrialization being developed in industrial countries, especially through computerization. The industrial world is alive and well, and industrial production is the main characteristic of our global economic world.

The internationalization of financial investment and the development of industrial delocalization have only fuelled the tendency towards greater inequality. The key shift, we think, is from an industrial world focused on the production of standard goods to a sustained emphasis on the production of singularized goods, more centrally targeted at the rich and more clearly disconnected from any "trickle-down economics" kind of justification. Our chief analytical point is to establish the extent to which this translates into different forms of classifying objects, of arguing about their value, their value understood, as we said, as the justification for the price. And there are certainly a number of ways of doing that. When we talk, for example, about a "collection form" in capitalism we refer to a particular style of valuation that is relevant for the interpretation of expensiveness.

FM:

Our readers would love a neat example.

\section{LB:}

Paul only needs a car to go once a week to the supermarket and he thinks that a second-hand car will do. He knows that Pierre has an 
old, run-down car stored in his garage. "How much?" he asks. "Well, about 30,000 euro", Pierre replies. "What? But it's forty years old!" Paul retorts, surprised. "It is a Renault Gordini", Pierre clarifies, adding that collectors are on the lookout for such a gem. Paul did not have control of the narrative that could rightly be used in order to criticize the price. He saw in the car merely an affordable means of transportation for a drive to the supermarket once a week and whose price could be assessed through a simple rule: the older the cheaper.

But here the "collection form" clearly wins. This is a problem of types of equivalences and the classification of goods. And this is our task: to map a system of equivalences that would not focus on the function or nature of objects, but rather on the ways and manners in which their price is justified. And from that viewpoint a Mercedes and a razor can very well be of the same kind, at some point. As they change hands and circulate in markets, objects can very well travel from one form to another, as Pierre's Renault Gordini, which can only become an expensive object once plunged in a particular "economy of enrichment" that emphasizes "memorial force".

\section{FM:}

Interestingly enough, there is an element of critique of capitalism and globalization in the narratives of the "collection form": preserving a sense of truthfulness and authenticity, protecting it from the impersonal reign of standardization, praising the love of vintage and the attachment to roots, demonstrating the fairness of expensiveness and the perils of low cost.

AE:

The economy of authenticity that is at work in, say, the terroir phenomenon indeed requires, in order just to make sense, the development of the "collection form". The terroir of course provides an illuminating case for the study of the conflation of an economic activity and a political discourse. Resisting homogeneity, replicability and disaffection are requisite conditions merely in order for terroir products to sell. Why is a Laguiole knife more expensive than a comparable knife, if not because of a reference to the town of Laguiole as the unique environment that nurtures know-how and authenticity?

FM:

And here is where the political dimension enters.

AE:

Indeed. When you have an entire economic order that is controlled by reference to the past, the question then is, how is this reference achieved? And, as we know, in order for a reference to the past to 
work, recourse to fiction is almost inevitably required. How is the past written and rewritten? If we ask which values we cling to, the answer is evidently determined by this writing of the past.

\section{FM:}

We end up again with the emerging connection between your interest in the "economy of enrichment" and your interest in the pragmatics of political critique.

\section{LB:}

Of course, these transformations are intimately linked to the transformations of the critique of capitalism, especially of its crisis in the late 1980s and subsequent reconstruction in the early 2000s. ${ }^{7}$ What we inherit from these transformations, to put it in a nutshell, is a critique aimed at what has been often called neoliberalism and which concentrates on the denunciation of a series of things that have to do with displacement and speed: the praise of global exchange, the acceleration of the pace of life, the absence of limits to economic conduct, the sense of reckless frenzy, the dissolution of recognizable identities.

But this focus, which sometimes wears the traits of fantasy, fuels a most remarkable transition from a critique of neoliberalism to a critique of liberalism, and opens from the Left a space for political discourse that is more and more articulated by the Right, in particular in its most extremist guise. In France, this articulation is most skilfully provided by the ideological work of Marine Le Pen, which exemplifies the crystallization of the template which today most widely serves the critique of capitalism, and which is the opposition between the rootless and the rooted.

\section{FM:}

From which follows a preoccupation with the praise for identity as a crucial ingredient of both the critique of capitalism and the dominant economic order.

\section{LB:}

And more to follow, as securing identities becomes perhaps the most crucial move of contemporary capitalistic order, which does not leave us short of contradictions.

\footnotetext{
7 See Boltanski and Chiapello (2005); Boltanski (2011).
} 


\section{References}

Boltanski, Luc. 2011. On Critique: A Sociology of Emancipation. Cambridge: Polity.

- 2012, Love and Justice as Competences: Three Essays on the Sociology of Action. Cambridge: Polity.

Boltanski, Luc, and Ève Chiapello. 2005. The New Spirit of Capitalism. London: Verso.

Boltanski, Luc, and Arnaud Esquerre. 2014a. "La 'collection', une forme neuve du capitalisme: la mise en valeur économique du passé et ses effets”. Les Temps Modernes 679: 5-72.

- 2014b. Vers l'extrême: extension des domains de la droite. Bellevaux: Éditions Dehors.

Boltanski, Luc, and Laurent Thévenot. 2006. On Justification: Economies of Worth. Princeton, NJ: Princeton University Press.

Luc Boltanski, sociologist, is a professor at the École des Hautes Études en Sciences Sociales (EHESS) in Paris, France, and the founder of the Groupe de Sociologie Politique et Morale (GSPM). Recent translations into English of his work include On Critique: A Sociology of Emancipation (Polity 2011); Love and Justice as Competences: Three Essays on the Sociology of Action (Polity 2012); and Mysteries and Conspiracies: Detective Stories, Spy Novels and the Making of Modern Societies (Polity 2014).

Arnaud Esquerre, sociologist, works at the Centre National de la Recherche Scientifique (CNRS) in France, and is a member of the Laboratoire d'Ethnologie et de Sociologie Comparative (LESC) at the Université Paris Ouest Nanterre La Défense. He is the author of $\mathrm{La}$ manipulation mentale: Sociologie des sectes en France (Fayard 2009); Les os, les cendres et l'État (Fayard 2011); and Prédire: L'astrologie en France au XXIe siècle (Fayard 2013). 